\title{
Effect of Oxygen on the Expression of Hypoxia-Inducible Factors in Human Fetal Lung Explants
}

\author{
Prapapan Rajatapiti ${ }^{a, d}$ Jessica D. de Rooij ${ }^{a, b} \quad$ Leonardus W.J.E. Beurskens ${ }^{a, b}$ \\ Richard Keijzer $^{a}$ Dick Tibboel ${ }^{a}$ Robbert J. Rottier ${ }^{a, c}$ Ronald R. de Krijger ${ }^{b}$ \\ a Department of Pediatric Surgery, Sophia Children's Hospital, b ${ }^{\text {Department }}$ of Pathology, Josephine Nefkens \\ Institute, and ' Department of Cell Biology and Genetics, Erasmus MC, University Medical Center Rotterdam, \\ Rotterdam, The Netherlands; ${ }^{\mathrm{d}}$ Department of Surgery, Faculty of Medicine, Chulalongkorn University, \\ Bangkok, Thailand
}

\section{Key Words}

Fetal lung development $\cdot$ Morphogenesis $\cdot$ Vascular endothelial growth factor $\cdot$ Hypoxia-inducible factors

\begin{abstract}
Background: Fetal lung development requires proper coordination between lung epithelial and vascular morphogenesis. A major determinant in lung vascular development is vascular endothelial growth factor (VEGF), which is regulated by hypoxia-inducible factors (HIFs). VEGF is expressed in the airway epithelium, while its receptors (VEGFRs) are expressed in the pulmonary mesenchyme. The hypoxic environment in utero is beneficial for fetal organogenesis, especially vascular development. However, little is known about the expression of HIFs and VEGFR-2 in the human fetal lung in vitro. Objectives: The purpose of this study was to investigate the effects of hypoxia on fetal lung morphology and mRNA expression of VEGF, VEGFR-2, HIF- $2 \alpha$, and HIF-3 $\alpha$. Methods: An explant culture technique was used to study the effects of normoxic and hypoxic conditions on human fetal lung. Results: The morphology remained largely unchanged in explants cultured under hypoxic or normoxic conditions. Quantitative RT-PCR showed that the mRNA expression of VEGF-A, but not VEGFR-2 is upregulated in explants cultured at $1.5 \%$ compared with $21 \%$ oxygen. We ob-
\end{abstract}

served a nonsignificant increase in HIF- $2 \alpha$ and HIF-3 $\alpha$ mRNA expression in explants cultured at $1.5 \%$ oxygen. These data suggest that the mRNA expression of VEGF, and possibly HIF$2 \alpha$ and HIF- $3 \alpha$, is regulated by hypoxia in the developing human lung. Conclusion: This lung explant culture model appears to be a valuable model to unravel the molecular mechanisms of human lung development.

Copyright $\odot 2009$ S. Karger AG, Basel

\section{Introduction}

The molecular basis of pulmonary development has been studied extensively over the past few decades. Many morphogens, growth and transcription factors have been shown to play key roles during different stages of this process [1-3]. Accumulating evidence underlines the importance of vascular development in relation to distal airway growth and development [4-6]. It is important to realize that normal prenatal (pulmonary) development occurs in a hypoxic environment. A number of studies have shown that hypoxia in utero is favorable for embryological organogenesis [5, 7-9].

P.R. and J.D. de R. contributed equally to this work.

\section{KARGER}

Fax +4161306 1234 E-Mail karger@karger.ch www.karger.com
(C) 2009 S. Karger AG, Basel

$1661-7800 / 10 / 0974-0346 \$ 26.00 / 0$

Accessible online at:

www.karger.com/neo
Dr. Ronald R. de Krijger

Department of Pathology, Josephine Nefkens Institute, Room Be222

Erasmus MC, University Medical Center Rotterdam, PO Box 2040

NL-3000 CA Rotterdam (The Netherlands)

Tel. +31 10408 7901, Fax +31 10408 9487, E-Mail R.deKrijger@erasmusmc.nl 
In mammalian systems, the cellular responses to oxygen alteration are mediated by hypoxia-inducible factors (HIFs), which are known to control more than 100 genes [10]. The HIF transcriptional complex is a heterodimer composed of one of the three oxygen-sensitive $\alpha$ subunits (HIF- $1 \alpha$, HIF- $2 \alpha$, or HIF- $3 \alpha$ ) and the constitutive HIF- $\beta$ subunit, alternatively called aryl hydrocarbon receptor nuclear translocator (ARNT) [11, 12]. Under hypoxic conditions, the HIF heterodimer is stable and accumulates into the nucleus where it binds to hypoxia response elements of target genes, thereby regulating their transcription. In normoxia, hydroxylation of the HIF- $\alpha$ subunit by prolyl hydroxylases (PHDs) mediates an interaction with the von Hippel-Lindau protein (pVHL), which subsequently leads to ubiquitination and targeting for proteasomal destruction $[11,13]$.

One of the most potent hypoxia-inducible growth factors is vascular endothelial growth factor-A (VEGF-A). VEGF-A signals through two high-affinity tyrosine kinase receptors, VEGF receptor (VEGFR)-1 (Flt-1), and VEGFR-2 (KDR in human or Flk-1 in mouse). In the lung, VEGF-A functions as a mitogen and differentiation factor for endothelial cells [14]. While VEGF-A is expressed mainly in the epithelial cells of the lung [15], VEGFRs are expressed in the mesenchymal cells immediately underlying the epithelium and vascular structures [16]. The level of VEGF is critical for normal lung development. Overexpression of VEGF in the distal lung airway epithelium alters vascularization and arrests airway branching [17], whereas inhibition of VEGF results in less complex alveolar patterning and immature lung formation [18]. Additionally, by using antisense oligonucleotides against HIF- $1 \alpha$ and VEGF, our group previously demonstrated that epithelial branching morphogenesis is abolished when pulmonary vascular development is inhibited [5]. The evidence that homozygous null VEGFR-2 mice die in utero as a result of a lack of mature endothelial cells and an absence of blood island formation, suggests a role of VEGFR-2 in mediating the mitogenic and chemotactic effect of VEGF-A on the endothelial cells [19].

The variation of oxygen tension leads to a variable phenotype of lung development. In vitro studies using rat lung explants cultured at $3 \%$ oxygen showed an increase in epithelial branching and cellular proliferation, as compared to explants cultured at $21 \%$ oxygen [9]. Previous studies in transgenic mouse lungs showed an increase in both epithelial and endothelial branching morphogenesis in explants cultured at $3 \%$ oxygen compared with $21 \%$ oxygen [5].

Effect of Hypoxia on Human Fetal Lung
Based on the aforementioned information, a low-oxygen environment of the fetus seems critical for pulmonary angiogenesis and possibly airway branching morphogenesis. Human lung explants maintained in vitro have been used in a number of studies on lung development [15, 20-27]. For instance, Acarregui et al. [15] previously showed the effect of a low oxygen level and cAMP on the expression of VEGF mRNA. However, there are very little data available regarding the expression of HIF$2 \alpha$, HIF- $3 \alpha$ and VEGFR- 2 in the human fetal lung in vitro. In this study, we used human fetal lung explants maintained in an in vitro culture system, to study the influence of low oxygen tension on the expression of HIF$2 \alpha$, HIF-3 $\alpha$, VEGF-A, and VEGFR2 in the developing human lung.

\section{Materials and Methods}

Lung Tissue and Explant Culture

This study was approved by the Medical Ethical Committee of the Erasmus MC University Medical Center Rotterdam and by the board of directors of the Center for Anticonception, Sexuality and Abortion (CASA) in Leiden.

Lung tissue was obtained from normal human fetuses after surgical termination of the pregnancy at 16, 17, 21, 22 and 22 weeks of gestation and after obtaining informed consent. No medication was used to abort the pregnancy. The obtained tissue fragments were rinsed with PBS and lung tissue was identified macroscopically. The lung fragments were preserved in cooled $\left(4^{\circ} \mathrm{C}\right)$ culture medium during transport. Within several hours, fetal lung tissue was carefully separated from the major blood vessels and airways, and dissected into 1 - to $2-\mathrm{mm}^{3}$ pieces. Lung explants (2-3 pieces) were placed separately on Nucleopore membranes (pore size $8 \mu \mathrm{m}$; Whatman, Den Bosch, The Netherlands), and cultured as air-liquid interface cultures in serum-free Waymouth's MB752/1 medium (Gibco, Breda, The Netherlands) with $1 \%$ penicillin-streptomycin and $1 \%$ insulin-transferrin-selenium (Gibco). The explants were maintained either under standard culture incubator conditions of $37^{\circ} \mathrm{C}$ and $5 \% \mathrm{CO}_{2} / 95 \%$ air $(21 \%$ oxygen; normoxia), or in an incubator with $5 \% \mathrm{CO}_{2}$, and $93.5 \%$ $\mathrm{N}_{2} / 1.5 \% \mathrm{O}_{2}$ (hypoxia). The culture medium was changed every $24 \mathrm{~h}$ and the explant tissue was harvested after 3 or 6 days of culture.

\section{Immunohistochemistry}

Immunohistochemistry was performed using the standard avidin-biotin complex method as previously published [28]. In brief, subsequent to deparaffinization in xylene and rehydration through graded alcohol steps, slides were treated with $3 \% \mathrm{H}_{2} \mathrm{O}_{2}$ in methanol to block the endogenous peroxidase activity. For antigen retrieval, slides were subjected to microwave treatment in citric acid buffer, pH 6.0 (Ki-67, TTF-1) or pronase (CD-31). After the blocking step, slides were incubated for $30 \mathrm{~min}$ at room temperature with a primary antibody against Ki-67 (1:150, Dako, Heverlee, Belgium), TTF-1 (1:100, Ab-1, Neomarkers, Calif., 
Table 1. Primer sequences for quantitative PCR

\begin{tabular}{lll}
\hline Gene & Forward primer $\left(5^{\prime} \rightarrow 3^{\prime}\right)$ & Reverse primer $\left(5^{\prime} \rightarrow 3^{\prime}\right)$ \\
\hline HIF2- $\alpha$ & CCA ATC CAG CAC CCA TCC CAC & GTT GTA GAT GAC CGT CCC CTG \\
HIF3- $\alpha$ & ACC TGG AAG GTG CTG AAC TG & AAT CCT GTC GTC ACA GTA GG \\
VEGF-A & AGA ATC ATC ACG AAG TGG TG & TGT TGT GCT GTA GGA AGC TC \\
VEGFR-2 & CAG AGT GGC AGT GAG CAA AG & TAC ACG ACT CCA TGT TGG TC \\
POLR2A & CGG ATG AAC TGA AGC GAA TG & AGC AGA AGA AGC AGA CAC AG \\
\hline
\end{tabular}

USA), or CD-31 (1:30, clone MIB-1, Dako). After rinsing with PBS, slides were incubated for $10 \mathrm{~min}$ with a biotinylated secondary antibody (Labvision, Calif., USA), followed by incubation with peroxidase-conjugated streptavidin (Labvision). Peroxidase activity was detected by diaminobenzidine tetrahydrochloride (Fluka, Buchs, Switzerland) in $0.3 \% \mathrm{H}_{2} \mathrm{O}_{2}$ and counterstained with hematoxylin. Negative controls were performed by omission of the primary antibodies.

\section{RNA Isolation and Quantitative RT-PCR}

Uncultured lung tissue and explants cultured for 3 and 6 days were used for quantitative PCR analysis. Total RNA was isolated using Trizol reagent according to the manufacturer's instructions (Invitrogen, Breda, The Netherlands). RNA was quantified by measuring the absorbance at $260 \mathrm{~nm}$ and the purity was checked by the 260/280-nm absorbance ratio. Total RNA ( $1 \mu \mathrm{g})$ was added to a reaction mixture containing $50 \mathrm{mM}$ Tris $-\mathrm{HCl}(\mathrm{pH} 8.3), 75 \mathrm{mM}$ $\mathrm{KCl}, 3 \mathrm{mM} \mathrm{MgCl}_{2}, 10 \mathrm{mM}$ dithiothreitol, $100 \mathrm{ng}$ random hexamer primer, $500 \mu \mathrm{M}$ of each deoxynucleotide triphosphate (dATP, dGTP, dCTP and dTTP), 10 U RNAse inhibitor and $200 \mathrm{U}$ Moloney murine leukemia virus reverse transcriptase (all reagents were obtained from Invitrogen). The RT thermal cycle was $1 \mathrm{~h}$ at $37^{\circ} \mathrm{C}$ followed by incubation for $15 \mathrm{~min}$ at $99^{\circ} \mathrm{C}$ (for primers see table 1).

Real-time PCR was performed using an iCycler IQ Real time PCR detection system (Bio-Rad, Veenendaal, The Netherlands) and qPCR Core kit for SYBR Green I (Eurogentech, Seraing, Belgium) with the following conditions: $10 \mathrm{~min}$ of initial denaturation at $95^{\circ} \mathrm{C}$ followed by 40 cycles of $95^{\circ} \mathrm{C}$ for $30 \mathrm{~s}, 58^{\circ} \mathrm{C}$ for $30 \mathrm{~s}, 60^{\circ} \mathrm{C}$ for $30 \mathrm{~s}$, and $75^{\circ} \mathrm{C}$ for $15 \mathrm{~s}$. The sequences for the genespecific primers used in this study can be found in table 1 . To verify the specificity of the amplified products, each PCR was followed by a melting curve analysis from 55 to $95^{\circ} \mathrm{C}$. Each sample was run in triplicate and mRNA of each target gene was determined simultaneously in a 96-well plate. Negative (no enzyme) and no-template (no cDNA) controls were also included. RNA polymerase II subunit A (POLR2A) was used as an internal reference for the relative quantitation of the PCR signals. The fold change was calculated as $2^{-\Delta \Delta C t}$ according to Livak and Schmittgen [29]. Lung tissue from day 0 (starting material) was used as a control group (arbitrary value $=1$ ).

\section{Statistical Analysis}

Data from the quantitative PCR are presented as mean $2^{-\Delta \Delta C t}$ \pm SEM. The differences between the experimental groups were evaluated using one-way ANOVA with post hoc least significant difference test. A p value of $<0.05$ was considered statistically significant. All statistics were calculated using SPSS statistical package (version 11.0; SPSS Inc., Chicago, Ill., USA).

\section{Results}

\section{Morphology of Human Fetal Lung Explants Cultured at $21 \%$ Oxygen}

To evaluate the feasibility of fetal lung explant culture in vitro under our conditions, human fetal lung explants derived from mid-trimester abortions were maintained at $21 \%$ oxygen for 6 days. Macroscopically, the explants appeared vital until at least 6 days of culture. The microscopic appearance of mid-trimester explants after culturing for 3 and 6 days resembled the pseudoglandular stage of lung development; except that the airways were dilated and the epithelial cells appeared flattened (fig. 1). To evaluate cell differentiation characteristics of the explants, sections of explants cultured for 3 and 6 days were immunostained with markers for epithelial cells (TTF1), endothelial cells (CD-31) and proliferation (Ki-67). There was no difference in the expression pattern of all markers between uncultured lungs and explants cultured for 3 or 6 days at $21 \%$ oxygen. Virtually all epithelial cells were positive for TTF-1 staining (fig. 2a, d, g), while endothelial cells were positive for CD-31 (fig. 2b, e, h). Ki-67 immunoreactivity was observed in both epithelial and mesenchymal cells (fig. 2c, f, i). Double immunohistochemical staining with $\mathrm{Ki}-67$ and CD-31 showed ongoing endothelial proliferation in the explants cultured under normoxic conditions after 6 days in culture (fig. 3b).

\section{Morphologic Changes Associated with Exposure to Hypoxia}

Sections of the explants were immunostained with Ki67, TTF-1 and CD-31 after culture for 6 days at either normoxic or hypoxic conditions. Uncultured tissue from 

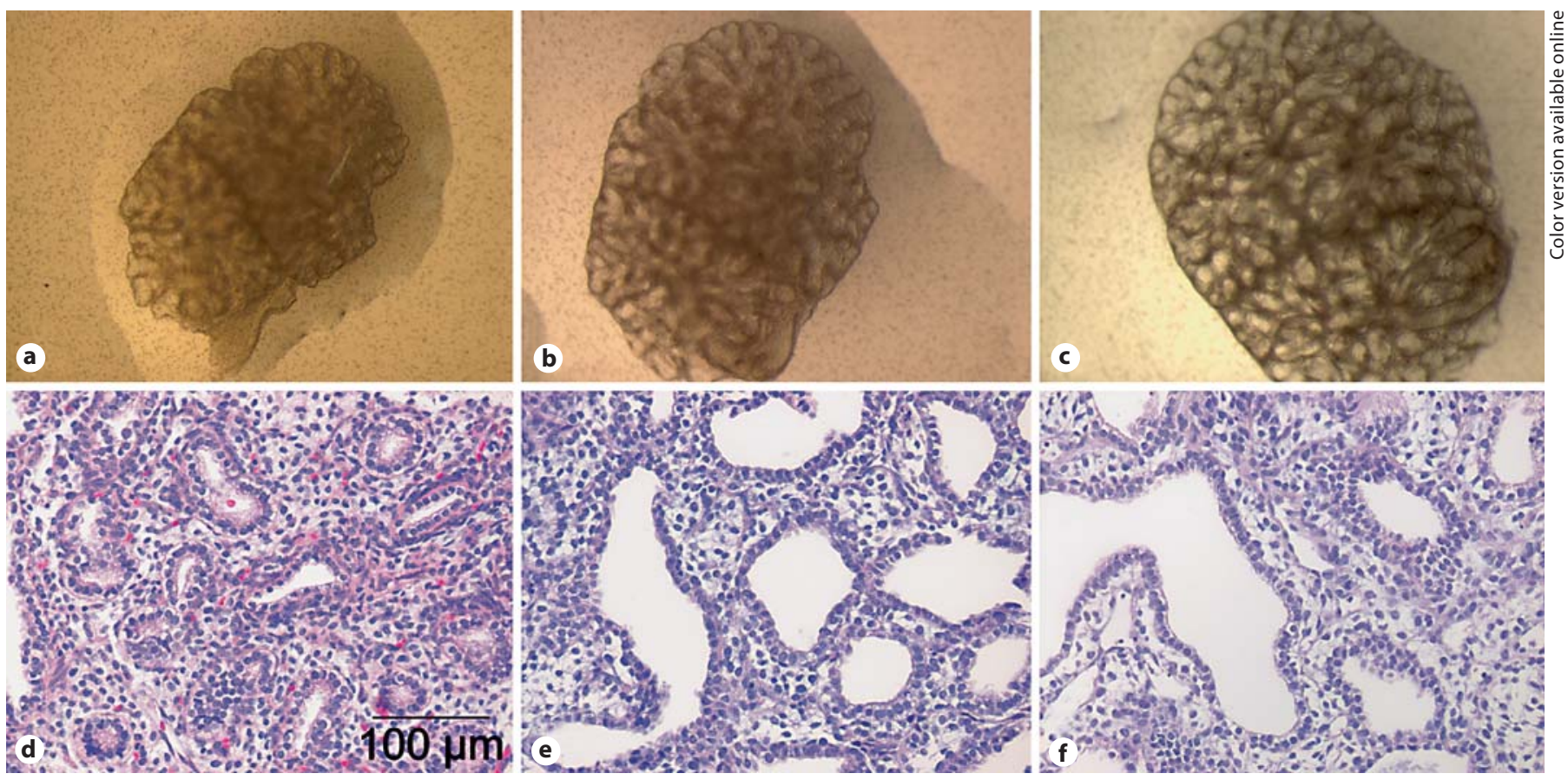

Fig. 1. Representative images showing the morphology of human fetal lung explants (gestational age 16 weeks) cultured at $21 \%$ oxygen. Macroscopic pictures of uncultured fetal lung explants (a) and after culture for 3 (b) and 6 days (c). Hematoxylin-eosin staining of uncultured lung (d) resembles the pseudoglandular stage of lung development. The airways are dilated after culture for 3 (e) and 6 days (f) at $21 \%$ oxygen. Bar $=100 \mu \mathrm{m}$.

the same patient was used as a control. The airways were larger in both hypoxic and normoxic cultured lungs at day 6 as compared to control tissue. There was no difference in the localization of TTF-1 (fig. $2 g, j$ ) and CD-31 (fig. $2 \mathrm{~h}, \mathrm{k}$ ) between explants cultured at 21 and $1.5 \%$ oxygen. However, CD-31 immunoreactivity appeared to be stronger in hypoxia-exposed lungs as compared to explants cultured at normoxia (fig. $2 \mathrm{k}$ vs. h). A proliferation marker, Ki-67, was expressed in both epithelial and mesenchymal cells in control tissue and explants cultured at $21 \%$ oxygen (fig. $2 \mathrm{c}, \mathrm{f}, \mathrm{i}$ ) but appeared to be more restricted to the epithelium in explants cultured at $1.5 \%$ oxygen (fig. 2l).

\section{Quantitative RT-PCR}

Quantitative RT-PCR showed that VEGF-A, VEGFR2 , HIF- $2 \alpha$, and HIF-3 $\alpha$ mRNA were expressed in all experimental groups. Relative mRNA expression of each gene was demonstrated as mean \pm SEM in figure $4(\mathrm{n}=$ 5 /group). There was an increase in VEGF-A mRNA expression in explants cultured at $1.5 \%$ oxygen compared with explants cultured at $21 \%$ oxygen and control ( $\mathrm{p} \leq$ 0.01). However, under hypoxic conditions, VEGF-A
mRNA expression was downregulated in explants cultured for 6 days compared with 3 days $(\mathrm{p}<0.01)$. There was no significant change in the expression of the other investigated genes between the explants cultured in normoxia and hypoxia, although the expression of HIF- $2 \alpha$ appeared higher in the explants cultured at $1.5 \%$ oxygen at day 3 compared with explants cultured at $21 \%$ oxygen without reaching statistical significance.

\section{Discussion}

The developing lung requires the formation and maintenance of a vascular network in close proximity to a layer of alveolar epithelial cells. In this study, we demonstrated that human lung explants cultured for 3-6 days at $1.5 \%$ oxygen maintain appropriate proliferation and differentiation of the airway epithelium as well as vascularization. Moreover, we demonstrated that VEGF-A mRNA expression was increased in the explants cultured under hypoxic conditions. In line with the increased expression of VEGF-A, we found that both HIF- $2 \alpha$ and HIF-3 $\alpha$ were slightly elevated in the hypoxic cultures, al- 

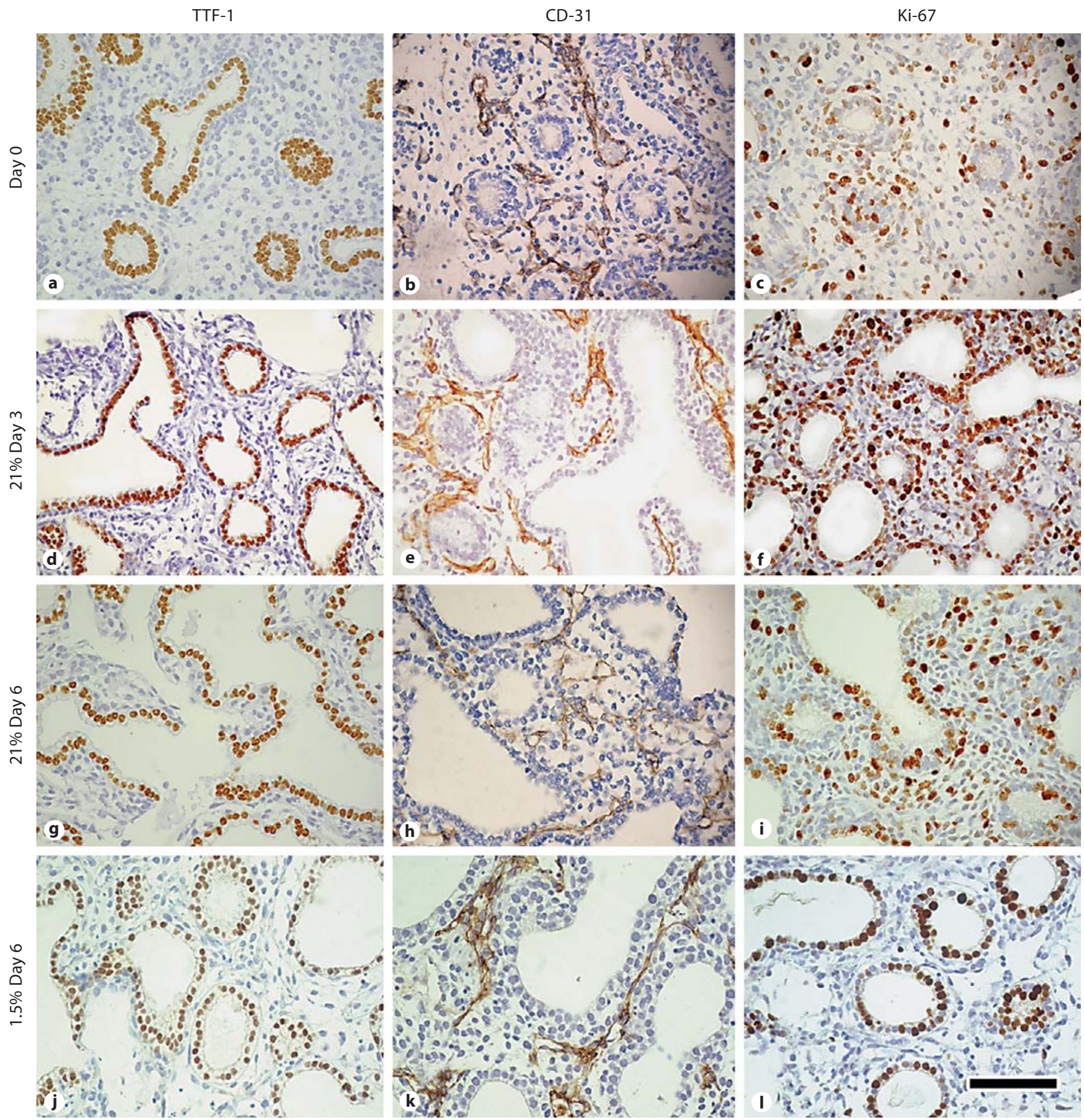

Fig. 2. Immunohistochemical staining with TTF-1, CD-31, and Ki-67 of uncultured lung (a-c), explants cultured at $21 \%$ for 3 (d-f) or 6 days (g-i), and $1.5 \%$ oxygen for 6 days $(\mathbf{j}-\mathbf{I})$. TTF-1 immunoreactivity is detected in epithelial cells $(\mathbf{a}, \mathbf{d}, \mathbf{g}, \mathbf{j})$. Explants cultured at $1.5 \%$ oxygen $(\mathbf{k})$ show stronger CD-31 staining of endothelial cells compared with control (b) and explants cultured at
$21 \%$ oxygen $(\mathbf{e}, \mathbf{h})$. Ki-67 staining $(\mathbf{c}, \mathbf{f}, \mathbf{i}, \mathbf{I})$ shows proliferating epithelial cells and mesenchymal cells in control (c) and explants kept at $21 \%$ oxygen $(\mathbf{f}, \mathbf{i})$, while the expression is more restricted to the epithelium in explants kept at $1.5 \%$ oxygen (I). Bar = $500 \mu \mathrm{m}$. 
Fig. 3. Double immunostaining of Ki-67 and CD-31 on explants cultured at $21 \%$ oxygen for 6 days. Ki-67 immunoreactivity is detected in epithelium and mesenchyme (a). Double staining with CD-31 (pink in the online version) shows proliferating endothelial cells (arrows; b). Bar $=250 \mu \mathrm{m}$.

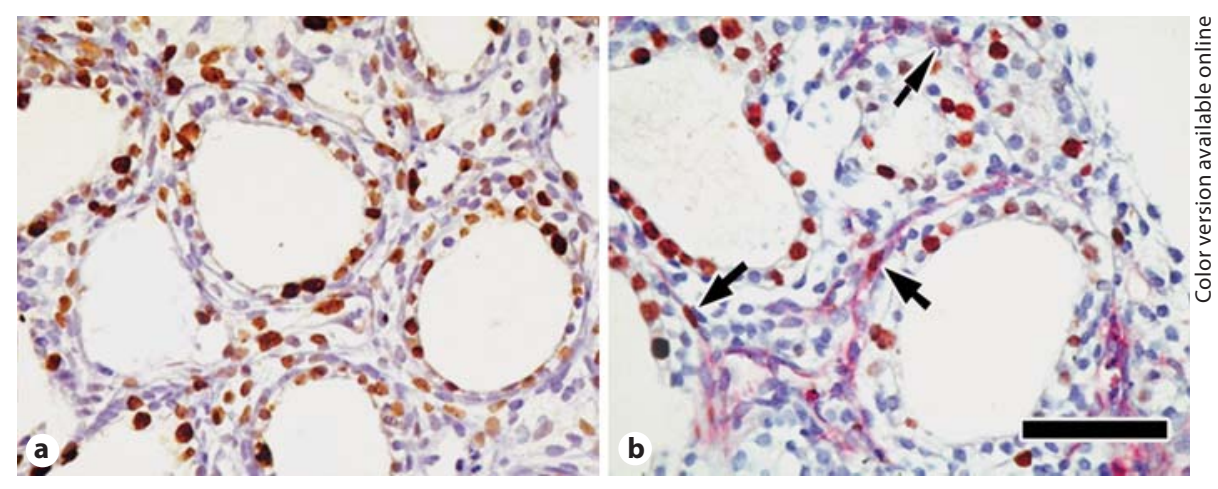

Table 2. Previous studies with human fetal lung explants

\begin{tabular}{|c|c|c|c|}
\hline Point of interest & Culture condition & Main results & Ref. \\
\hline \multicolumn{4}{|l|}{ Morphological change } \\
\hline Cell differentiation & $20 \% \mathrm{O}_{2}$ & $\begin{array}{l}\text { Spontaneous differentiation of airway epithelium into type II } \\
\text { pneumocytes }\end{array}$ & 20 \\
\hline Apoptosis & $20 \% \mathrm{O}_{2}$ & $\uparrow$ Number of cell undergoing apoptosis especially in the interstitium & 25 \\
\hline In response to hyperoxia & 95 vs. $20 \% \mathrm{O}_{2}$ & $\begin{array}{l}\downarrow \text { Number of vessels and VEGF mRNA expression in hyperoxia } \\
\downarrow \text { Cell proliferation in the interstitium but not in epithelium }\end{array}$ & 27 \\
\hline \multicolumn{4}{|l|}{ Surfactant protein } \\
\hline Effects of $\mathrm{O}_{2}$ & 70 or 95 vs. $20 \%$ & $\uparrow$ SP-A, SP-C mRNA, SP-B unchanged & 24,30 \\
\hline Effects of retinoic acid & \pm retinoic acid & $\downarrow$ SP-A, SP-C mRNA, $\uparrow$ SP-B mRNA & 22 \\
\hline Effects of glucocorticoids & \pm dexamethasone & $\uparrow \mathrm{SP}-\mathrm{A}$ mRNA at lower concentration but $\downarrow$ at concentration $>10^{-8} \mathrm{M}$ & 21 \\
\hline \multicolumn{4}{|l|}{ VEGF pathway } \\
\hline Effects of $\mathrm{O}_{2}$, cAMP & $\begin{array}{l}2 \text { vs. } 20 \% \mathrm{O}_{2} \\
\pm \text { cAMP }\end{array}$ & $\begin{array}{l}\uparrow \text { VEGF mRNA and protein after } 2-4 \text { days in } 2 \% \mathrm{O}_{2} \\
\text { cAMP } \uparrow \text { VEGF mRNA in } 20 \% \text { but not } 2 \%\end{array}$ & 15 \\
\hline \multirow[t]{2}{*}{ Effect of exogenous VEGF } & \pm recombinant & VEGFR-2 expressed in distal airway epithelium & 26 \\
\hline & VEGF & $\begin{array}{l}\text { Exogenous VEGF } \uparrow \text { epithelium volume density, tissue differentiation and } \\
\uparrow S P-A, \text { SP-C mRNA, SP-B unchanged }\end{array}$ & \\
\hline
\end{tabular}

though the differences with normoxic cultures were not statistically significant.

Fetal lung explants maintained in vitro are a wellcharacterized model for studying fetal lung development. The differentiation of mid-gestational human fetal lung explants in culture has been characterized both biochemically and morphologically in several studies $[15,20-22$, $24-27,30]$, as depicted in table 2 . However, there is little information on the role of hypoxia at the cellular level in human fetal lung development. Previous studies in murine lungs have shown that hypoxia enhances the development of pulmonary vasculature and airway epithelial branching morphogenesis, as compared to ambient oxygen $[5,9]$.

Effect of Hypoxia on Human Fetal Lung
In the present study, the airway epithelium of the explants appeared flattened within a dilated airspace after being maintained at 1.5\% oxygen for 6 days. There was no obvious difference in the localization of epithelium(TTF-1) and endothelium- (CD31) specific markers between human lung explants cultured at 1.5 or $21 \%$ oxygen. Immunostaining with the proliferation marker Ki67 showed that cells in the lung explants were still dividing. A formal quantification of cell proliferation was not performed, due to the small number of samples. These findings indicate that the cultured lung tissue maintains its normal structure and growth capacity.

The close anatomical relationship between airways and blood vessels in the lung suggests their putative in- 
Fig. 4. Relative mRNA expression of VEGF-A, VEGFR-2, HIF- $2 \alpha$, and HIF- $3 \alpha$ in human fetal lung explants maintained for 3 or 6 days in $21 \% \mathrm{O}_{2}(\mathrm{Nd} 3$ and $\mathrm{Nd} 6$, respectively) or $1.5 \% \mathrm{O}_{2}(\mathrm{Hd} 3$ and $\mathrm{Hd} 6$, respectively) and uncultured lungs (d0). For relative quantification, the expression of POLR2A mRNA was used as reference gene. Bars represent means $\pm \operatorname{SEM}(n=5)$. The expression of VEGF-A mRNA is upregulated in explants cultured at $1.5 \%$ oxygen ( $\mathrm{Hd} 3$ and $\mathrm{Hd} 6$ ) as compared to explants cultured at $21 \%$ oxygen $(\mathrm{Nd} 3$ and $\mathrm{Nd} 6$ ) and control (d0), but its expression in explants kept at hypoxic conditions is decreased when cultured for a longer period (Hd6 vs. Hd3). * $\mathrm{p} \leq 0.01$ vs. d0, Nd3, and Nd6; ${ }^{*} \mathrm{p}<0.01$ vs. Hd3.

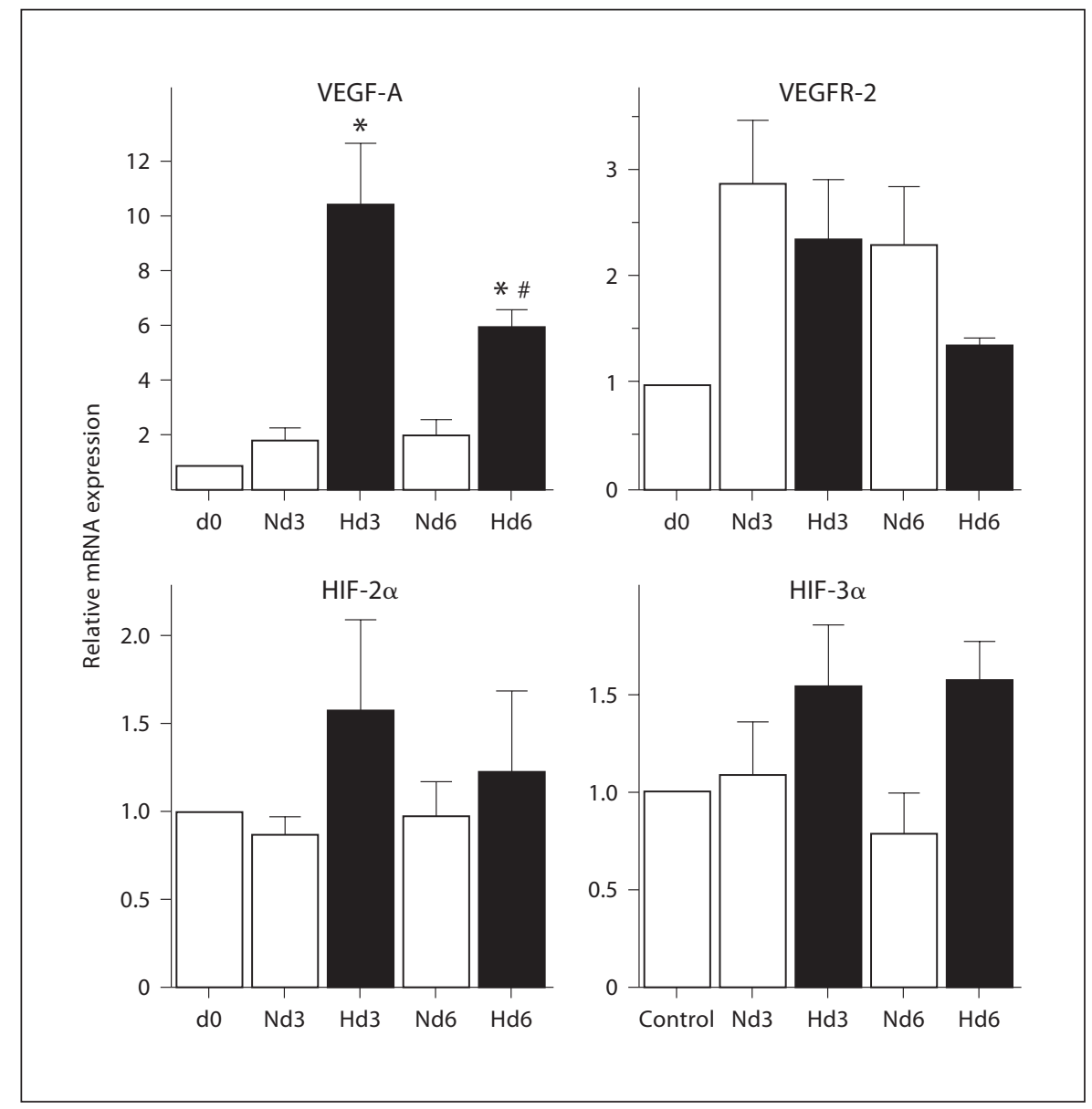

teraction during development. The inhibition of vascularization in mouse lungs in vitro results in a decrease in epithelial branching morphogenesis [5, 31]. VEGF has been shown to act as a potent inducer of endothelial cell growth and hypoxia is one of its most important stimuli $[14,15]$. VEGF is essential for embryonic development, as it was shown that inactivation of a single VEGF allele results in embryonic lethality with impaired vessel formation $[14,32]$. In this study, we have shown that VEGFA mRNA expression is significantly upregulated in lung explants cultured at $1.5 \%$ oxygen, as compared to normoxic conditions. Similar findings have been reported for VEGF expression in human [15], mouse [5], and rat [9] fetal lung explants cultured at low oxygen. However, these studies have not established the relationship with expression of HIFs and VEGF. Our results confirm that low oxygen stimulates VEGF expression and probably vascular development in human fetal lung development.
The expression of VEGFR-2 is stimulated by HIF- $2 \alpha$ [33], but there are no reports of an oxygen-dependent upregulation of VEGFR-2 expression in human lung. Previous studies in lung explants of a transgenic mouse model have shown that VEGFR-2 mRNA expression was significantly increased after 2 days in culture under hypoxic conditions. However, with extension of the culture period, this difference was no longer noticeable [5]. Our results also showed no significant difference in the expression of VEGFR-2 mRNA between 1.5 and 21\% oxygen after 3 or 6 days in culture. Apparently, factors other than hypoxia are also important in the expression of VEGF receptors in human pulmonary mesenchyme. It is possible that the expression of VEGFR-2 is oxygen-dependent, but the effect of oxygen was already diminished when we studied the cultured tissue at day 3 .

VEGF gene transcription is activated by hypoxia through HIF-1 $\alpha$ and HIF-2 $\alpha$ [34-36]. These two factors have a close sequence similarity, but their modes of ex- 
pression vary greatly, and HIF- $1 \alpha$ and HIF- $2 \alpha$ have unique targets [10]. HIF-1 $\alpha$ is ubiquitously expressed in the developing embryo [37] and in the lung, where it is detected in the branching epithelium of the first-trimester lung but also in some mesenchymal cells [16]. HIF-1 $\alpha$ double-knockout mice die in utero at e10.5 with cardiac, vascular defects and extensive cell death $[38,39]$. HIF- $2 \alpha$ is abundantly expressed in murine adult lungs under normoxic conditions [34, 40], especially in the developing mesenchyme and vasculature [37]. HIF-2 $\alpha$-null mice die in the embryonic stage with abnormal lung maturation and blood vessel defects [41], and a defect in catecholamine production [35]. However, a subset of HIF- $2 \alpha$ knockout offspring survives postnatally but suffers from respiratory distress due to surfactant deficiency [42]. Another member of the HIF family, HIF- $3 \alpha$, appears to be involved in negative regulation of the angiogenic response through an alternative splice variant, inhibitory PAS domain protein (IPAS) [43]. IPAS can be induced by hypoxia in the heart and lung resulting in a negative feedback loop for HIF-1 $\alpha$ activity in these tissues [44]. A previous study in adult mice by Heidbreder et al. [40] reported that mRNA expression of HIF-3 $\alpha$, but not HIF- $2 \alpha$ increased significantly corresponding to the duration of systemic hypoxia. In addition, they found an increase in both HIF- $2 \alpha$ and HIF-3 $\alpha$ protein levels [40]. In the A549 cell line, HIF- $1 \alpha$ and HIF- $3 \alpha$ showed a different response to hypoxia $\left(1 \% \mathrm{O}_{2}\right)$, which led to the suggestion that HIF$3 \alpha$ is complementary rather than redundant to HIF- $1 \alpha$ induction [45]. Our analysis with quantitative PCR showed only a slight increase in HIF- $2 \alpha$ and HIF- $3 \alpha$ mRNA expression in explants cultured under hypoxic conditions at day 3 , but this difference was not significant. However, it must be noted that the regulation of HIF- $\alpha$ factors is mainly post-transcriptional, and therefore this could very well explain the marginal differences between the hypoxic and normoxic cultures [13]. So, aside from the presence of both HIF- $2 \alpha$ and HIF- $3 \alpha$, we showed that the expression of their main target, VEGF-A, is significantly upregulated upon hypoxia. This indicates that although the expression of both factors is only slightly elevated, the transcriptional activity of the HIF factors is increased under hypoxic conditions. At this point, we cannot discriminate whether HIF- $2 \alpha$ or HIF- $3 \alpha$ is the main inducer of VEGF.

In summary, this study has demonstrated that fetal human lung explants exposed to hypoxia (1.5\% oxygen) maintain proper epithelial and mesenchymal morphogenesis. An increase in VEGF-A expression under hypoxic conditions suggests its role in regulating pulmonary vascular and airway development. Human fetal lung explants maintained in a serum-free system allowed us to focus on the local effects of oxygen tension rather than a systemic response to hypoxia. Moreover, the establishment of this model of normal human fetal lung development might also open up the possibility of studying abnormal lung development such as pulmonary hypoplasia resulting from obstructive uropathy and oligohydramnios, or in case of congenital diaphragmatic hernia. A better understanding of the abnormal processes in these conditions will enhance our knowledge of the pathogenesis of pulmonary defects. In addition, this model can be applied to investigate the effect of different ligands or medications that have an effect on lung development such as retinoic acid and steroid hormone. This may provide us with new therapeutic interventions, both pre- and postnatally.

\section{Acknowledgements}

This research was funded by the Sophia Foundation for Scientific Research, Rotterdam, The Netherlands (SSWO project No. 411). The authors wish to thank the staff, physicians and nurses of CASA Leiden for their cooperation and hospitality.

\section{References}

1 Shannon JM, Hyatt BA: Epithelial-mesenchymal interactions in the developing lung. Annu Rev Physiol 2004;66:625-645.

-2 Cardoso WV, Lu J: Regulation of early lung morphogenesis: questions, facts and controversies. Development 2006;133:1611-1624.

$\checkmark 3$ Maeda Y, Dave V, Whitsett JA: Transcriptional control of lung morphogenesis. Physiol Rev 2007;87:219-244.

4 Gebb SA, Shannon JM: Tissue interactions mediate early events in pulmonary vasculogenesis. Dev Dyn 2000;217:159-169.
5 van Tuyl M, Liu J, Wang J, Kuliszewski M, Tibboel D, Post M: Role of oxygen and vascular development in epithelial branching morphogenesis of the developing mouse lung. Am J Physiol Lung Cell Mol Physiol 2005;288:167-178.

-6 Del Moral PM, Sala FG, Tefft D, Shi W, Keshet E, Bellusci S, Warburton D: VEGF-A signaling through Flk-1 is a critical facilitator of early embryonic lung epithelial to endothelial crosstalk and branching morphogenesis. Dev Biol 2006;290:177-188.
7 Yue X, Tomanek RJ: Stimulation of coronary vasculogenesis/angiogenesis by hypoxia in cultured embryonic hearts. Dev Dyn 1999; 216:28-36.

$>8$ Loughna S, Yuan HT, Woolf AS: Effects of oxygen on vascular patterning in Tiel/LacZ metanephric kidneys in vitro. Biochem Biophys Res Commun 1998;247:361-366.

$\checkmark 9$ Gebb SA, Jones PL: Hypoxia and lung branching morphogenesis. Adv Exp Med Biol 2003;543:117-125. 
10 Hu CJ, Wang LY, Chodosh LA, Keith B, Simon MC: Differential roles of hypoxia-inducible factor 1alpha (HIF-1alpha) and HIF2alpha in hypoxic gene regulation. Mol Cell Biol 2003;23:9361-9374.

11 Maxwell PH: Hypoxia-inducible factor as a physiological regulator. Exp Physiol 2005; 90:791-797.

12 Hirota K, Semenza GL: Regulation of angiogenesis by hypoxia-inducible factor 1 . Crit Rev Oncol Hematol 2006;59:15-26.

13 Pugh CW, Ratcliffe PJ: Regulation of angiogenesis by hypoxia: role of the HIF system. Nat Med 2003;9:677-684.

14 Ferrara N: Vascular endothelial growth factor: basic science and clinical progress. Endocr Rev 2004;25:581-611.

15 Acarregui MJ, Penisten ST, Goss KL, Ramirez K, Snyder JM: Vascular endothelial growth factor gene expression in human fetal lung in vitro. Am J Respir Cell Mol Biol 1999;20:1423.

16 Groenman F, Rutter M, Caniggia I, Tibboel D, Post M: Hypoxia-inducible factors in the first trimester human lung. J Histochem $\mathrm{Cy}$ tochem 2007;55:355-363.

17 Akeson AL, Greenberg JM, Cameron JE, Thompson FY, Brooks SK, Wiginton D, Whitsett JA: Temporal and spatial regulation of VEGF-A controls vascular patterning in the embryonic lung. Dev Biol 2003;264: 443-455.

18 Gerber HP, Hillan KJ, Ryan AM, Kowalski J, Keller GA, Rangell L, Wright BD, Radtke F, Aguet M, Ferrara N: VEGF is required for growth and survival in neonatal mice. Development 1999;126:1149-1159.

19 Shalaby F, Rossant J, Yamaguchi TP, Gertsenstein M, Wu XF, Breitman ML, Schuh AC: Failure of blood-island formation and vasculogenesis in Flk-1-deficient mice. Nature 1995;376:62-66.

- 20 Snyder JM, Johnston JM, Mendelson CR: Differentiation of type II cells of human fetal lung in vitro. Cell Tissue Res 1981;220:1725.

21 Boggaram V, Smith ME, Mendelson CR: Regulation of expression of the gene encoding the major surfactant protein (SP-A) in human fetal lung in vitro. Disparate effects of glucocorticoids on transcription and on mRNA stability. J Biol Chem 1989;264: 11421-11427.

22 Metzler MD, Snyder JM: Retinoic acid differentially regulates expression of surfactant-associated proteins in human fetal lung. Endocrinology 1993;133:1990-1998.

-23 Acarregui MJ, Snyder JM, Mendelson CR: Oxygen modulates the differentiation of human fetal lung in vitro and its responsiveness to cAMP. Am J Physiol 1993;264:L465L474.
24 Acarregui MJ, Kumar AR, Penisten ST, Snyder JM: $\mathrm{O} 2$ regulates surfactant protein a mRNA transcription and stability in human fetal lung in vitro. Am J Physiol 1998;274: 343-350.

25 Scavo LM, Ertsey R, Chapin CJ, Allen L, Kitterman JA: Apoptosis in the development of rat and human fetal lungs. Am J Respir Cell Mol Biol 1998;18:21-31.

26 Brown KR, England KM, Goss KL, Snyder JM, Acarregui MJ: VEGF induces airway epithelial cell proliferation in human fetal lung in vitro. Am J Physiol Lung Cell Mol Physiol 2001;281:1001-1010.

27 Bustani P, Hodge R, Tellabati A, Li J, Pandya $\mathrm{H}$, Kotecha S: Differential response of the epithelium and interstitium in developing human fetal lung explants to hyperoxia. Pediatr Res 2006;59:383-388.

28 Gontan C, de Munck A, Vermeij M, Grosveld F, Tibboel D, Rottier R: Sox 2 is important for two crucial processes in lung development: branching morphogenesis and epithelial cell differentiation. Dev Biol 2008;317:296-309.

29 Livak KJ, Schmittgen TD: Analysis of relative gene expression data using real-time quantitative PCR and the 2(-Delta Delta C(T)) method. Methods 2001;25:402-408.

30 Acarregui MJ, Brown JJ, Mallampalli RK: Oxygen modulates surfactant protein mRNA expression and phospholipid production in human fetal lung in vitro. Am J Physiol 1995; 268:L818-L825.

-31 Schwarz MA, Wan Z, Liu J, Lee MK: Epithelial-mesenchymal interactions are linked to neovascularization. Am J Respir Cell Mol Biol 2004;30:784-792.

- 32 Carmeliet P, Ferreira V, Breier G, Pollefeyt S, Kieckens L, Gertsenstein M, Fahrig M, Vandenhoeck A, Harpal K, Eberhardt C, Declercq C, Pawling J, Moons L, Collen D, Risau W, Nagy A: Abnormal blood vessel development and lethality in embryos lacking a single VEGF allele. Nature 1996;380:435439.

33 Elvert G, Kappel A, Heidenreich R, Englmeier U, Lanz S, Acker T, Rauter M, Plate K, Sieweke M, Breier G, Flamme I: Cooperative interaction of hypoxia-inducible factor-2alpha (HIF-2alpha) and Ets-1 in the transcriptional activation of vascular endothelial growth factor receptor-2 (Flk-1). J Biol Chem 2003;278:7520-7530.

34 Ema M, Taya S, Yokotani N, Sogawa K, Matsuda Y, Fujii-Kuriyama Y: A novel bHLHPAS factor with close sequence similarity to hypoxia-inducible factor lalpha regulates the VEGF expression and is potentially involved in lung and vascular development. Proc Natl Acad Sci USA 1997;94:42734278.
35 Tian H, Hammer RE, Matsumoto AM, Russell DW, McKnight SL: The hypoxia-responsive transcription factor EPAS1 is essential for catecholamine homeostasis and protection against heart failure during embryonic development. Genes Dev 1998;12:33203324

-36 Semenza GL: HIF-1: mediator of physiological and pathophysiological responses to hypoxia. J Appl Physiol 2000;88:1474-1480.

- 37 Jain S, Maltepe E, Lu MM, Simon C, Bradfield CA: Expression of ARNT, ARNT2, HIF1 alpha, HIF2 alpha and Ah receptor mRNAs in the developing mouse. Mech Dev 1998;73:117-123.

38 Iyer NV, Kotch LE, Agani F, Leung SW, Laughner E, Wenger RH, Gassmann M, Gearhart JD, Lawler AM, Yu AY, Semenza GL: Cellular and developmental control of $\mathrm{O} 2$ homeostasis by hypoxia-inducible factor 1 alpha. Genes Dev 1998;12:149-162.

-39 Kotch LE, Iyer NV, Laughner E, Semenza GL: Defective vascularization of HIF-1alpha-null embryos is not associated with VEGF deficiency but with mesenchymal cell death. Dev Biol 1999;209:254-267.

40 Heidbreder M, Frohlich F, Johren O, Dendorfer A, Qadri F, Dominiak P: Hypoxia rapidly activates HIF-3alpha mRNA expression. FASEB J 2003;17:1541-1543.

41 Peng J, Zhang L, Drysdale L, Fong GH: The transcription factor EPAS-1/hypoxia-inducible factor 2alpha plays an important role in vascular remodeling. Proc Natl Acad Sci USA 2000;97:8386-8391.

-42 Compernolle V, Brusselmans K, Acker T, Hoet P, Tjwa M, Beck H, Plaisance S, Dor Y, Keshet E, Lupu F, Nemery B, Dewerchin M, Van Veldhoven P, Plate K, Moons L, Collen D, Carmeliet P: Loss of HIF-2alpha and inhibition of VEGF impair fetal lung maturation, whereas treatment with VEGF prevents fatal respiratory distress in premature mice. Nat Med 2002;8:702-710.

43 Makino Y, Cao R, Svensson K, Bertilsson G, Asman M, Tanaka H, Cao Y, Berkenstam A, Poellinger L: Inhibitory PAS domain protein is a negative regulator of hypoxia-inducible gene expression. Nature 2001;414: 550-554.

-44 Makino Y, Kanopka A, Wilson WJ, Tanaka $\mathrm{H}$, Poellinger L: Inhibitory PAS domain protein (IPAS) is a hypoxia-inducible splicing variant of the hypoxia-inducible factor-3alpha locus. J Biol Chem 2002;277:3240532408.

45 Li QF, Wang XR, Yang YW, Lin H: Hypoxia upregulates hypoxia inducible factor (HIF)3alpha expression in lung epithelial cells: characterization and comparison with HIF1alpha. Cell Res 2006;16:548-558. 